\title{
Carbon monoxide-releasing molecules protect against blue light exposure and inflammation in retinal pigment epithelial cells
}

\author{
PO-MIN YANG ${ }^{1}$, KAI-CHUN CHENG ${ }^{2,3}$, SHAO-HO YUAN $^{4}$ and BEING-SUN WUNG ${ }^{4}$ \\ ${ }^{1}$ Department of Ophthalmology, Chiayi Christian Hospital, Chiayi 60002; ${ }^{2}$ Department of Ophthalmology, \\ Kaohsiung Municipal Hsiao-kang Hospital, Kaohsiung 81267; ${ }^{3}$ Department of Ophthalmology, \\ Kaohsiung Medical University Hospital, Kaohsiung 807378; ${ }^{4}$ Department of Microbiology, \\ Immunology and Biopharmaceuticals, National Chiayi University, Chiayi 60002, Taiwan, R.O.C.
}

Received October 30, 2019; Accepted May 25, 2020

DOI: $10.3892 / \mathrm{ijmm} .2020 .4656$

\begin{abstract}
The most common cause of vision loss among the elderly is age-related macular degeneration (AMD). The aim of the present study was to investigate the potential cytoprotective and anti-inflammatory effects of carbon monoxide-releasing molecules (CORMs), and their ability to activate the expression of nuclear factor erythroid 2-related factor 2 (Nrf2)-related genes in human retinal pigment epithelium (RPE) cells, as well as the inhibition of endothelial cell migration. It was first determined that CORM2 and CORM3 suppressed blue light-induced cell damage. In addition, a decrease in the level of cleaved poly(ADP-ribose) polymerase 1 protein and dissipation of mitochondrial membrane potential were considered to reflect the anti-apoptotic activity of CORMs. Furthermore, CORM2 induced Nrf-2 activation and the expression of the Nrf2-related genes heme oxygenase- 1 and glutamate-cysteine ligase. Pretreatment with CORM2 abolished the blue light-induced increase in oxidative stress, suggesting that CORM2-induced antioxidant activity was involved in the cytoprotection against blue light. It was also demonstrated that CORMs markedly suppressed tumor necrosis factor (TNF) $\alpha$-induced intercellular adhesion molecule-1 expression. Moreover, it was further observed that CORMs exert their inhibitory effects through blocking nuclear factor- $\kappa \mathrm{B} / \mathrm{p} 65$ nuclear translocation and IкB $\alpha$ degradation in TNF $\alpha$-treated RPE cells. It was observed that CORM2, but not CORM3, protected against oxidative stress-induced cell damage. CORMs abolished vascular endothelial growth factor-induced migration of endothelial cells. The findings of the present study demonstrated the cytoprotective, antioxidant and anti-inflammatory effects of CORMs on RPE cells and
\end{abstract}

Correspondence to: Dr Being-Sun Wung, Department of Microbiology, Immunology and Biopharmaceuticals, National Chiayi University, 300 Shiuefu Road, Chiayi 60002, Taiwan, R.O.C. E-mail: bswung@mail.ncyu.edu.tw

Key words: carbon monoxide, blue light, nuclear factor- $\kappa \mathrm{B}$, glutathione, retinal pigment epithelial cells anti-angiogenic effects on endothelial cells, suggesting the potential clinical application of CORMs as anti-AMD agents.

\section{Introduction}

Age-related macular degeneration (AMD) is the leading cause of blindness in the elderly, which manifests by progressive loss of central vision through degeneration at the ocular interface between the retina and the underlying choroid (1). A typical characteristic non-neovascular (dry) form of AMD is the formation of drusen and geographic atrophy, whereas the exudative (wet) form involves blood vessel invasion. Vascular endothelial growth factor (VEGF) is known to play a pivotal role in the growth of abnormal blood vessels that characterize the wet form of AMD (2).

The retinal pigment epithelium (RPE) is firmly attached to the underlying choroid and is a monolayer of cells that plays critical roles in retinal homeostasis, eye development and vision. Dysfunction of RPE cells induces photoreceptor dystrophy, retinal diseases and blindness. It was previously demonstrated that the blue light-induced pathological changes of RPE cells resemble AMD (3). Since RPE cells are sensitive to blue light, which may trigger cellular apoptosis, blue light exposure is considered as a suitable model for AMD study.

Exacerbated oxidative stress and inflammation in the RPE contribute to the pathogenesis of AMD, eventually leading to RPE degeneration (4). The migration of macrophages and lymphocytes to the posterior compartment of the eye and the secretion of proinflammatory cytokines are characteristic during ocular inflammation (5). RPE cells are a component of the outer blood-retinal barrier and respond to the macrophage-secreted proinflammatory cytokine tumor necrosis factor (TNF) $\alpha$ (6). Leukocyte recruitment and adhesion to the retina are mediated by intercellular adhesion molecule (ICAM)-1 (7). The inflammatory nuclear factor (NF)- $\kappa \mathrm{B}$ pathway plays a key role in $\mathrm{TNF} \alpha$-activated ICAM-1 expression (8).

The RPE is sensitive to blue light, which causes oxidative stress and RPE cell damage at certain doses (9). Nuclear factor erythroid 2-related factor 2 (Nrf2)-derived heme oxygenase (HO)-1 and the synthesis of glutathione (GSH) have been found to act as critical antioxidants in vivo and in vitro (10-12). 
GSH maintains a reduced cellular environment and is part of a protective mechanism against numerous cellular stressors (13). Therefore, protecting RPE cells from blue light or oxidative stress through engendering a Nrf2-regulated cell redox state may provide a potential target for AMD treatment.

Carbon monoxide-releasing molecules (CORMs) have been demonstrated to act pharmacologically by mimicking the bioactive effects of HO-1 and CO gas (14-16). Low concentrations of $\mathrm{CO}$ have been found to increase resistance to cell damage and apoptosis in various model systems (17). Since $\mathrm{CO}$ has exhibited the ability to mediate a number of biological functions, including anti-inflammation, cell cycle arrest and vasodilation, it has shown potential for use in various therapeutic applications $(17,18)$. However, the cytoprotective mechanism of $\mathrm{CO}$ in RPE cells remains unclear. Thus, the present study was designed to determine the molecular mechanisms underlying the cytoprotective properties of CORMs in RPE cells. There are two widely used CORMs: The lipid-soluble CORM2 $\left\{\left[\mathrm{Ru}(\mathrm{CO})_{3} \mathrm{Cl}_{2}\right]_{2}\right\}$ and the water-soluble CORM3 $\left[\mathrm{Ru}(\mathrm{CO})_{3} \mathrm{Cl}_{2}\left(\mathrm{H}_{2} \mathrm{NCH}_{2} \mathrm{CO}\right)_{2}\right]$ (19). It was herein investigated whether these CORMs possess protective properties that may contribute to the CO-regulated cytoprotective effects.

\section{Materials and methods}

Materials. NF- $\kappa \mathrm{B} /$ Luc vectors were constructed as described previously (20). ICAM-1/CD54 antibody (cat. no. 4915S; 1:1,000) was purchased from Cell Signaling Technology, Inc. NF- $\mathrm{B} / \mathrm{p} 65$ antibody (cat. no. KAS-TF110; 1:1,000) was purchased from Stressgen Biotechnologies. Antibodies against IкBa (cat. no. sc-847; 1:1,000), poly(ADP-ribose) polymerase 1 (PARP-1) (cat. no. sc-136208; 1:200) and lamin (cat. no. sc-6217; 1:1,000) were purchased from Santa Cruz Biotechnology, Inc. Tubulin antibody (cat. no. T568; 1:1,000) was obtained from Sigma-Aldrich; Merck KGaA. Peroxidase-conjugated anti-rabbit (cat. no. G-21040; 1:1,000) and anti-mouse (cat. no. 31460; 1:2,500) antibodies were obtained from Invitrogen (Thermo Fisher Scientific, Inc.) and nitrocellulose was obtained from Schleicher and Schuell. The luciferase assay kit (cat. no. E1500) was purchased from Promega Corporation. All other reagents, including TNF- $\alpha$ and VEGF-A proteins, were purchased from Sigma-Aldrich; Merck KGaA.

RPE cell culture and blue light exposure. The human RPE cell line ARPE-19 was obtained from ATCC and cultured in DMEM-Ham's F12 (1:1; Invitrogen; Thermo Fisher Scientific, Inc.) containing 10\% FBS (Invitrogen; Thermo Fisher Scientific, Inc.). The cells were grown for 3 days until reaching 90-100\% confluence. The medium was replaced with fresh serum-free DMEM-Ham's F12, and the cells were grown for an additional $12 \mathrm{~h}$ prior to experimental treatment. ARPE-19 cells were cultured in the dark or irradiated with blue light (400 nm) at an intensity of 2,000 \pm 500 lux for $24 \mathrm{~h}$ to establish the light-induced injury model.

Endothelial cell and THP-1 cell cultures. The human umbilical vein cell line EA.hy926 (ATCC CRL-2922) was cultured in DMEM (Gibco-BRL; Thermo Fisher Scientific, Inc.) supplemented with $10 \% \mathrm{FBS}$ at $37^{\circ} \mathrm{C}$ under $5 \% \mathrm{CO}_{2}$. The
THP-1 cells (ATCC ${ }^{\circledR}$ TIB202 ${ }^{\mathrm{TM}}$ ) were cultured in RPMI-1640 medium containing $10 \% \mathrm{FBS}$ at $37^{\circ} \mathrm{C}$ under $5 \% \mathrm{CO}_{2}$.

Cell viability assay. Cell viability was assayed using Alamar Blue (Serotec) according to the manufacturer's instructions. This assay identifies live cell metabolic activity by detecting redox activity in cells. The excitation/emission wavelength settings were adjusted to $530 / 590 \mathrm{~nm}$.

Morphological analysis after DAPI staining. Cells were fixed with $4 \%$ paraformaldehyde for $15 \mathrm{~min}$ at room temperature and then stained with DAPI for $5 \mathrm{~min}$ in the dark at room temperature. After washing with PBS for $5 \mathrm{~min}$, the cells were analyzed under a fluorescence microscope (Axiovert S100; Carl Zeiss AG) at a magnification of $x 200$. The normal cell nucleus is round, has clear borders and is uniformly stained, whereas apoptotic cells exhibit nuclear pyknosis, irregular edges and strong staining.

Analysis of intracellular reactive oxygen species (ROS). To detect intracellular ROS production, RPE cells were seeded into 96-well plates $\left(2 \times 10^{4}\right.$ cells/well) in DMEM-F12 for $24 \mathrm{~h}$ and incubated in serum-free DMEM-F12 for $12 \mathrm{~h}$ prior to experimental treatment. Next, the cells were incubated with $20 \mu \mathrm{M}$ peroxide-sensitive fluorescent probe carboxy- $\mathrm{H}_{2}$ DCFDA (Molecular Probes, LLC) for $30 \mathrm{~min}$. After washing with PBS twice (5-10 min per wash), the cells were solubilized with $1 \%$ SDS and $5 \mathrm{mM}$ Tris- $\mathrm{HCl}$ (pH 7.4). Fluorescence was measured with a spectrofluorophotometer (model Rf-5301PC; Shimadzu Corporation) with excitation and emission wavelengths of 450 and $520 \mathrm{~nm}$, respectively. The cells were observed and images were captured with a fluorescence microscope (Axiovert S100; Carl Zeiss AG) at a magnification of x200.

Determination of GSH and oxidized glutathione (GSSG) levels. The intracellular level of reduced GSH was determined as previously described (21). Briefly, cells were incubated with the fluorescent probe monochlorobimane $(40 \mathrm{mM}$; cat. no. HY-101899; Sigma-Aldrich; Merck KGaA) for $20 \mathrm{~min}$ at room temperature in the dark. After washing with PBS twice (5-10 min per wash), the cells were solubilized with $5 \mathrm{mM}$ Tris- $\mathrm{HCl}(\mathrm{pH} 7.4)$ and $1 \%$ SDS. Fluorescence was measured using a spectrofluorophotometer (Rf-5301PC; Shimadzu Corporation) at an excitation wavelength of $390 \mathrm{~nm}$ and an emission wavelength of $520 \mathrm{~nm}$. For GSSG analysis, the GSH scavenger 1-methyl-2-vinylpyridinium trifluoromethane sulfonate was added, and the GSSG levels were then determined spectrophotometrically using the GSH reductase-linked 5,5'-dithiobis(2-nitrobenzoic acid).

Western blotting. Total protein was extracted from ARPE-19 cells using RIPA buffer (1\% NP-40, 0.5\% sodium deoxycholate, $0.1 \%$ SDS) and a protease inhibitor mixture and separated by $10 \%$ SDS-PAGE. The nitrocellulose membrane (EMD Millipore) needed for the transfer was hydrated in cold Tris-glycine buffer $(\mathrm{pH} \mathrm{8.3)}$ at $10 \mathrm{~V}$ for $1.5 \mathrm{~h}$. The membranes were blocked with TBS containing $5 \%$ non-fat milk and incubated for $2 \mathrm{~h}$ at room temperature, followed by incubation with primary antibodies against ICAM-1 (cat. no. 4915S; 1:1,000; Cell Signaling Technology, 
Inc.), NF- $\kappa \mathrm{B} / \mathrm{p} 65$ (cat. no. KAS-TF110; 1:1,000; Stressgen Biotechnologies), IкBa (cat. no. sc-847; 1:1,000; Santa Cruz Biotechnology, Inc.), PARP-1 (cat. no. sc-136208; 1:200; Santa Cruz Biotechnology, Inc.), lamin (cat. no. sc-6217; 1:1,000; Santa Cruz Biotechnology, Inc.) and tubulin (cat. no. T568; 1:1,000; Sigma-Aldrich; Merck KGaA) overnight at $4^{\circ} \mathrm{C}$ with gentle shaking. After incubation with the primary antibodies, the membranes were washed with TBS with 5\% non-fat milk and incubated with horseradish peroxidase-conjugated anti-rabbit (cat. no. G-21040; 1:1,000; Invitrogen; Thermo Fisher Scientific, Inc.) and anti-mouse (cat. no. 31460; 1:2,500; Invitrogen; Thermo Fisher Scientific, Inc.) antibodies for $2 \mathrm{~h}$ at $4^{\circ} \mathrm{C}$. Immunoreactive bands were visualized with enhanced chemiluminescence solution (EMD Millipore).

Mitochondrial membrane potential assay. ARPE-19 cells $\left(1.5 \times 10^{4}\right.$ cells/well) were cultured in a 12 -well plate and exposed to blue light for $24 \mathrm{~h}$. The measurement of mitochondrial membrane potential was performed using JC-1 dye (Mitochondrial Membrane Potential Probe; Invitrogen; Thermo Fisher Scientific, Inc.). The cells were washed with PBS for $5 \mathrm{~min}$ and incubated with $10 \mu \mathrm{g} / \mathrm{ml} \mathrm{JC}-1$ at $37^{\circ} \mathrm{C}$ for $15 \mathrm{~min}$ in the dark. Images were captured using a fluorescence microscope (Axiovert S100; Carl Zeiss AG; magnification, $\mathrm{x} 400$ ), which detects healthy cells with JC-1 J-aggregates (excitation/emission, 540/605 nm) and unhealthy cells with mostly JC-1 monomers (excitation/emission, 480/510 nm). The quantification of the images was performed with ImageJ software, version 1.8.0 (National Institutes of Health).

Monocyte adhesion assay. Cells grown to 90-100\% confluence in a 96-well plate were pretreated with CORMs and/or TNFa for $6 \mathrm{~h}$ to allow for the expression of ICAM-1. The cells were co-cultured with $5 \times 10^{5}$ calcein-labeled THP-1 cells for $30 \mathrm{~min}$. After washing twice with RPMI-1640 medium, adherent cells were examined using an ELISA plate reader (FLx800, Bio-Tek Instruments, Inc.) at $485 \mathrm{~nm}$ excitation and $538 \mathrm{~nm}$ emission wavelengths (22).

Immunofluorescence staining. ARPE-19 cells were pretreated with the test compounds for $2 \mathrm{~h}$ at $37^{\circ} \mathrm{C}$ prior to exposure to $\mathrm{TNF} \alpha$. The cells were fixed in $80 \%$ ethanol at room temperature for $10 \mathrm{~min}$ and treated with $0.1 \%$ (v/v) Triton X-100 in PBS. After blocking with 3\% BSA (Sigma-Aldrich; Merck KGaA) for $1 \mathrm{~h}$ at room temperature, the cells were incubated with mouse monoclonal antibody (anti-NF- $\kappa \mathrm{B} / \mathrm{p} 65$ antibody diluted 1:100 in PBS) overnight at $4^{\circ} \mathrm{C}$. Subsequently, the cells were incubated with Alexa Fluor 488 goat anti-mouse IgG $(\mathrm{H}+\mathrm{L}$; A28175; 1:1,000; Invitrogen; Thermo Fisher Scientific, Inc.) for $1 \mathrm{~h}$. Cell nuclei were stained with propidium iodide $(10 \mathrm{ng} / \mathrm{ml}$ in PBS) at room temperature for $30 \mathrm{~min}$ in the dark and images were captured using a by Zeiss Axiovert S100 fluorescence microscope (Carl Zeiss AG).

Nuclear and cytoplasmic protein extraction. ARPE-19 cells were collected by scraping in cold PBS and pelleted by centrifugation at $1,000 \mathrm{x}$ for $5 \mathrm{~min}$ at $4^{\circ} \mathrm{C}$. The cell pellet was resuspended in the cell lysis buffer (including $10 \mathrm{mM}$ HEPES, $1.5 \mathrm{mM} \mathrm{MgCl}$, $10 \mathrm{mM} \mathrm{KCl}, 0.5 \mathrm{mM}$ dithiothreitol, $0.5 \mathrm{mM}$ phenylmethanesulfonyl fluoride and
$0.3 \%$ Nonidet P-40) and then centrifuged at $12,000 \times \mathrm{g}$ for 5 min at $4^{\circ} \mathrm{C}$. The collected supernatant was designated as the cytoplasmic fraction. Nuclear proteins were then extracted using a buffer containing $20 \mathrm{mM}$ HEPES, 25\% glycerol, $1.5 \mathrm{mM} \mathrm{MgCl} 2,0.6 \mathrm{M} \mathrm{KCl}$ and $0.2 \mathrm{mM}$ EDTA.

$R N A$ isolation and reverse transcription-PCR (RT-PCR) analysis. Total RNA was isolated using the TRIzol reagent according to the manufacturer's instructions (Invitrogen; Thermo Fisher Scientific, Inc.). Equal quantities $(5 \mu \mathrm{g})$ of RNA from the cells receiving various treatments were then reverse-transcribed using 50 units of Superscript II (Invitrogen; Thermo Fisher Scientific, Inc.) for $50 \mathrm{~min}$ at $42^{\circ} \mathrm{C}$. PCR was performed in a $25-\mu 1$ reaction mixture containing $10 \mathrm{mM}$ Tris- $\mathrm{HCl}, 50 \mathrm{mM} \mathrm{KCl}, 5 \mathrm{mM} \mathrm{MgCl}_{2}$, $0.1 \%$ Triton X-100 (pH 9.0) and 0.6 U Taq DNA polymerase (Promega Corporation). The primers $(30 \mathrm{pmol})$ used for the amplification of glutamate-cysteine ligase (GCL) modifier subunit (GCLM), GCL catalytic subunit (GCLC), ICAM-1 and GAPDH were as follows: GCLM forward, 5'-CAGCGA GGAGCTTCATGATTG-3' and reverse, 5'-TGATCACAG AATCCAGCTGTGC-3'; GCLC forward, 5'-GTTCTTGAA ACTCTGCAAGAGAAG-3' and reverse, 5'-ATGGAGATG GTGTATTCTTGTCC-3'; ICAM-1 forward, 5'-AGCAATGTG CAAGAAGATAGCCAA-3' and reverse, 5'-GGTCCCCTG CGTGTTCCACC-3'; GAPDH forward, 5'-TATCGTGGA AGGACTCATGACC-3' and reverse, 5'-TACATGGCAACTG TGAGGGG-3'. The thermocycling conditions were as follows: 1 cycle of $5 \mathrm{~min}$ at $95^{\circ} \mathrm{C}$, followed by 30 cycles of $40 \mathrm{sec}$ at $95^{\circ} \mathrm{C}, 30 \mathrm{sec}$ at $59^{\circ} \mathrm{C}\left(62^{\circ} \mathrm{C}\right.$ for GCLC $)$, and $50 \mathrm{sec}$ at $72^{\circ} \mathrm{C}$, with a final extension at $72^{\circ} \mathrm{C}$ for $5 \mathrm{~min}$. Reaction products were separated electrophoretically on a $2.5 \%$ agarose gel and stained with ethidium bromide.

Plasmids, transfections, and measurement of luciferase activity. The ARPE-19 cells were transfected with $1 \mu \mathrm{g}$ of $\mathrm{NF}-\kappa \mathrm{B} /$ Luc or p3xARE/Luc using Lipofectamine 3000 (Invitrogen; Thermo Fisher Scientific, Inc.) according to the manufacturer's instructions. Briefly, the reporter DNA $(2 \mu \mathrm{g})$ and $\beta$-galactosidase DNA $(0.5 \mu \mathrm{g})$ were mixed with $5 \mu \mathrm{l}$ Lipofectamine 3000 for $10 \mathrm{~min}$ at room temperature. The mixture was added to ARPE-19 cells and, $4 \mathrm{~h}$ later, $10 \%$ FBS DMEM/F-12 was added for $24 \mathrm{~h}$. For the luciferase assays, the cell lysate was mixed with luciferase substrate solution (Promega Corporation), and then the resultant luciferase activity was measured using the FB12 Tube Luminometer (Titertek-Berthold). The luciferase activities were standardized to $\beta$-galactosidase activity.

Scratch assay for endothelial cell (EC) migration. For the wound healing assay, $1.5 \times 10^{5}$ ECs per well were cultured for $24 \mathrm{~h}$ in a 12 -well plate with serum-free DMEM. When the cells had grown to $90-100 \%$ confluence, the cell monolayer was scratched with a $200-\mu l$ pipette tip, washed twice with DMEM, and incubated in a serum-free medium with $10 \mathrm{ng} / \mathrm{ml}$ VEGF-A alone, or $10 \mathrm{ng} / \mathrm{ml}$ VEGF-A with CORMs. Cell migration and wound closure was monitored, and images were captured at 0 , 12 and 24 h using a phase-contrast Axiovert S100 microscope (Carl Zeiss AG). Photographs were taken at 12 and $24 \mathrm{~h}$ after wounding. The distance migrated by the ECs to close the 


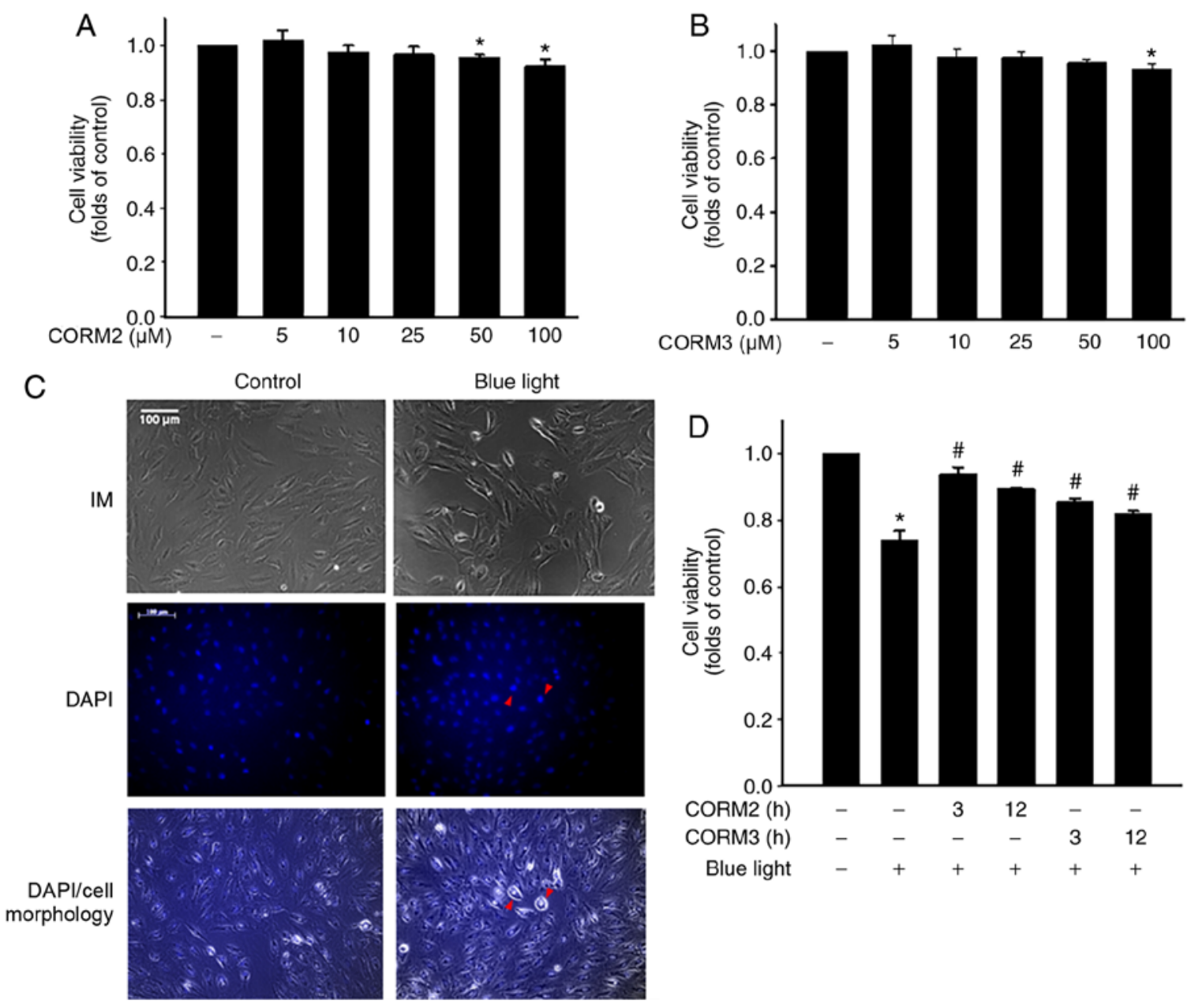

Figure 1. Cytoprotective activity of CORMs in RPE cells. (A and B) RPE cells were incubated with CORM2 or CORM3 at the indicated concentrations for $24 \mathrm{~h}$ and cell viability was measured. Data are expressed as mean \pm standard error. ${ }^{*} \mathrm{P}<0.05$ compared with the untreated cells. (C) RPE cells were stimulated with blue light for $24 \mathrm{~h}$, the morphological changes were observed under an inverted microscope (IM) and pyknotic nuclei were detected by DAPI staining. Red arrowheads indicate the nuclei with apoptotic-like morphological changes. Scale bar, $100 \mu \mathrm{m}$. (D) RPE cells were preincubated with or without $25 \mathrm{mM}$ CORM2 and CORM 3 for the indicated times, stimulated with blue light for $24 \mathrm{~h}$, and cell viability was measured. "P<0.05 compared with the untreated cells, ${ }^{\#} \mathrm{P}<0.05$ compared with blue light alone. RPE, retinal pigment epithelium; CORM, carbon monoxide-releasing molecule.

wounded area was measured. The quantification of the area was analyzed with ImageJ software, version 1.8.0 (National Institutes of Health). Results are expressed as a migration index calculated from the slope of the distance-time curve at $0,6,12$, 18 and 24 h relative to the slope of the VEGF-treated cells.

Transwell migration assay. Cell migration assays were performed using Transwell plates with $8-\mu \mathrm{m}$ pore filters (Corning, Inc.), following the manufacturer's protocol. Briefly, for the cell migration assay, cells $\left(2 \times 10^{5}\right)$ were suspended in $200 \mu \mathrm{l}$ of serum-free medium and seeded into the upper chambers of the Transwell plates; serum-free medium supplemented with $10 \mathrm{ng} / \mathrm{ml}$ VEGF-A was applied to the lower chamber as a chemoattractant to induce migration. After incubation for $24 \mathrm{~h}$ at $37^{\circ} \mathrm{C}$, cells were fixed with $4 \%$ cold paraformaldehyde for $15 \mathrm{~min}$ at room temperature and stained with $0.1 \%$ crystal violet solution for $5 \mathrm{~min}$ at room temperature. Non-migrating cells remaining on the upper surface of the filter membrane were scraped off gently with a cotton swab. For quantification, the stained cells that had migrated to the other side of the membrane were extracted with $33 \%$ acetic acid. The absorbance of the eluted stain was determined at $570 \mathrm{~nm}$.
Statistical analysis. Values are expressed as the mean \pm standard error of at least three experiments. Statistical significance was assessed through one-way analysis of variance, followed by Tukey's post hoc test using SigmaPlot version 12 (Systat Software, Inc.). $\mathrm{P}<0.05$ was considered to indicate statistically significant differences.

\section{Results}

CORMs reduce blue light-induced cytotoxicity in RPE cells. To determine whether CO could protect RPE cells from stress, the viability of ARPE-19 cells treated with CORM2 and CORM3 was first determined. As shown in Fig. 1A and B, CORM2 and CORM3 at $25 \mathrm{mM}$ did not exert a cytotoxic effect on ARPE-19 cells. Subsequently, the protective effects of CORMs against blue light-induced cytotoxicity were examined in RPE cells. First, after exposure to blue light for $24 \mathrm{~h}$, some RPE cells were shrunk and their nuclei were condensed, as detected by DAPI staining (Fig. 1C). Pretreating cells with $25 \mathrm{mM}$ CORM2 or CORM3 for 3 or $12 \mathrm{~h}$ significantly prevented this blue light-induced cytotoxicity (Fig. 1D), with the protective effect of CORM2 being superior to that of 
A

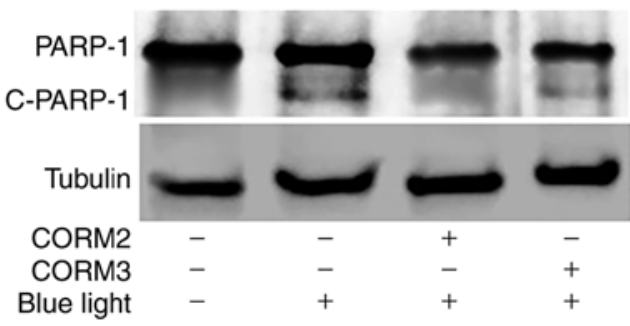

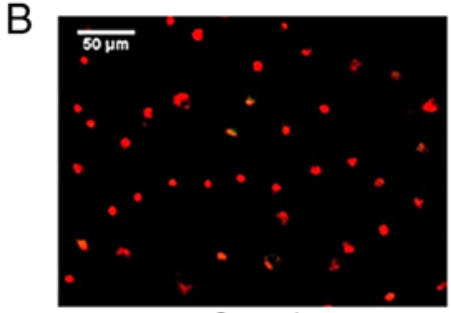

Control

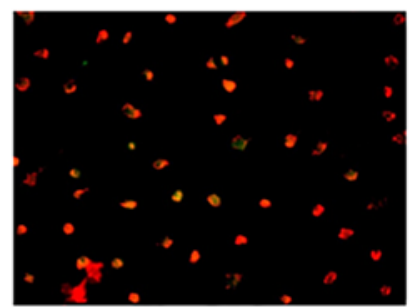

Blue light+

CORM2

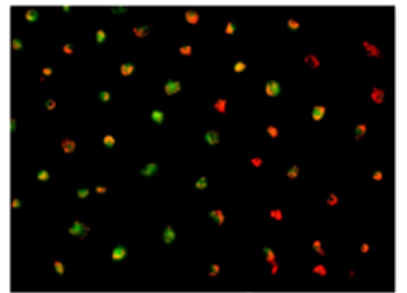

Blue light

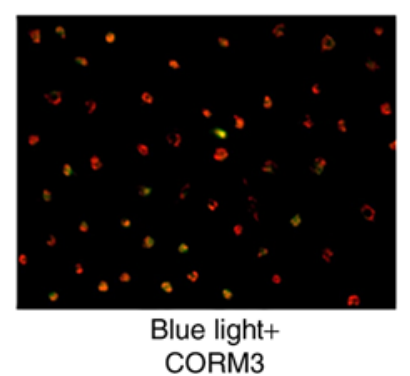

C

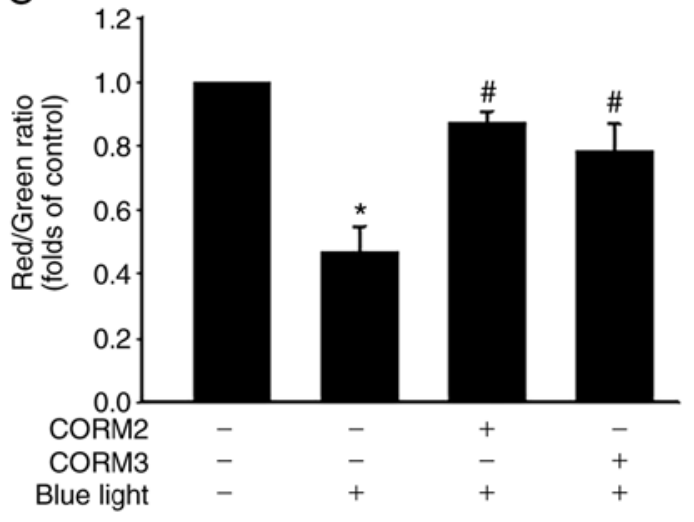

Figure 2. CORMs reduce blue light-induced cytotoxicity in RPE cells. (A) RPE cells were preincubated with or without $25 \mu \mathrm{M}$ CORM2 and CORM3 for $3 \mathrm{~h}$ and stimulated with blue light for $24 \mathrm{~h}$. Cell lysates were detected by western blotting with anti-PARP-1. (B) Mitochondrial membrane potential was evaluated using JC-1 dye. Red fluorescence indicates healthy mitochondria and green fluorescence indicates mitochondria in injured cells with low membrane potential. Scale bar, $50 \mu \mathrm{m}$. (C) The fluorescent images of mitochondrial membrane potential of RPE cells were determined by the fluorescent dye JC-1 under a fluorescence microscope and expressed as red/green fluorescence intensity ratios. ${ }^{*} \mathrm{P}<0.05$ compared with the untreated cells, ${ }^{\sharp} \mathrm{P}<0.05$ compared with blue light alone. RPE, retinal pigment epithelium; CORM, carbon monoxide-releasing molecule; PARP-1, poly(ADP-ribose) polymerase 1; c-PARP-1, cleaved PARP-1.

CORM3. To elucidate whether CORM2 or CORM3 could attenuate blue light-induced cytotoxicity, the expression of cleaved PARP-1, which is one of the downstream effectors of caspase-3, was detected by immunoblotting. As shown in Fig. 2A, the blue light-induced cleaved PARP-1 expression was markedly suppressed by pre-incubation with CORM2 or CORM3. Subsequently, the protective mechanisms of CORM2 and CORM3 were compared to investigate the effect of blue light on mitochondrial activity using JC-1 fluorescence and the results are shown in Fig. 2B. As seen in the representative images, the red fluorescence intensity was increased by $25 \mathrm{mM}$ CORM2 or CORM3 pretreatment compared to that of the blue light-treated cells (Fig. 2C). These results suggest that CORM2 and CORM3 effectively inhibited blue light-induced apoptosis by maintaining the mitochondrial membrane potential.

The antioxidant activity of CORM2 is mediated through an increase in the GSH level. A Previous study demonstrated that inflammatory cytokines increase the production of ROS through mitochondria and NADPH oxidases in cultured RPE cells (23). To determine the antioxidant properties of CORMs, the protective effects of CORM2 and CORM3 against oxidative stress were first examined by subjecting the cells to $1 \mathrm{mM} \mathrm{H}_{2} \mathrm{O}_{2}$ for $1 \mathrm{~h}$. Pretreating cells with $25 \mathrm{mM}$ CORM2 for $12 \mathrm{~h}$ significantly prevented oxidative stress-induced cell death (Fig. 3A). As shown in Fig. 3B, CORM2 treatment for $3 \mathrm{~h}$ increased the HO-1 level. GSH is the most abundant antioxidant $n$ maintaining cellular redox status (12). The enzyme involved in the de novo synthesis of GSH is GCL, which comprises GCLC and GCLM subunits. Treatment with CORM2 increased the GCLC and GCLM expression levels over the course of the incubation period (Fig. 3C). As indicated in Fig. 3D, the reduced GSH levels were increased after $3 \mathrm{~h}$ of CORM2 treatment. However, the GSSG levels were found to have increased slightly at $3 \mathrm{~h}$ of CORM 2 treatment (Fig. 3E). CORM2, but not CORM3, caused an increase in Nrf2 transcriptional activity with ARE-luciferase reporter construct in RPE cells (Fig. 3F). These findings suggested that CORM2 pretreatment exerted a stronger antioxidant effect compared with CORM3. As shown in Fig. 4A and B, blue light exposure induced ROS generation in RPE cells and increased intracellular ROS levels in a time-dependent manner. In addition, CORM2 inhibited blue light-induced oxidative stress (Fig. 4C). Taken together, these results demonstrated that CORM2 exerted an antioxidant effect and abolished blue light-increased oxidative stress in RPE cells.

CORM2 and CORM3 inhibit monocyte adhesion and ICAM-1 expression. To detect the anti-inflammatory properties of CORMs in RPE cells, the effects of CORMs on monocyte adhesion to ARPE-19 were examined. We discovered that $\mathrm{TNF} \alpha$ significantly increased monocyte adhesion, which was 

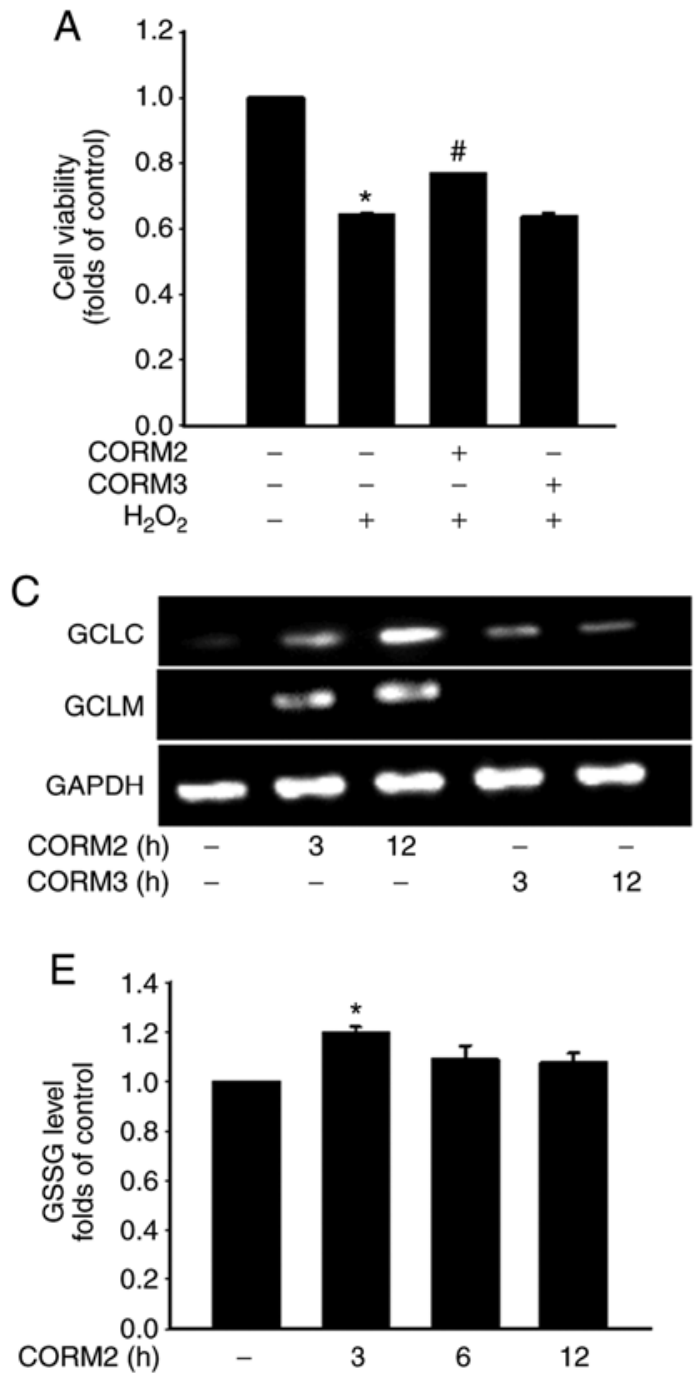
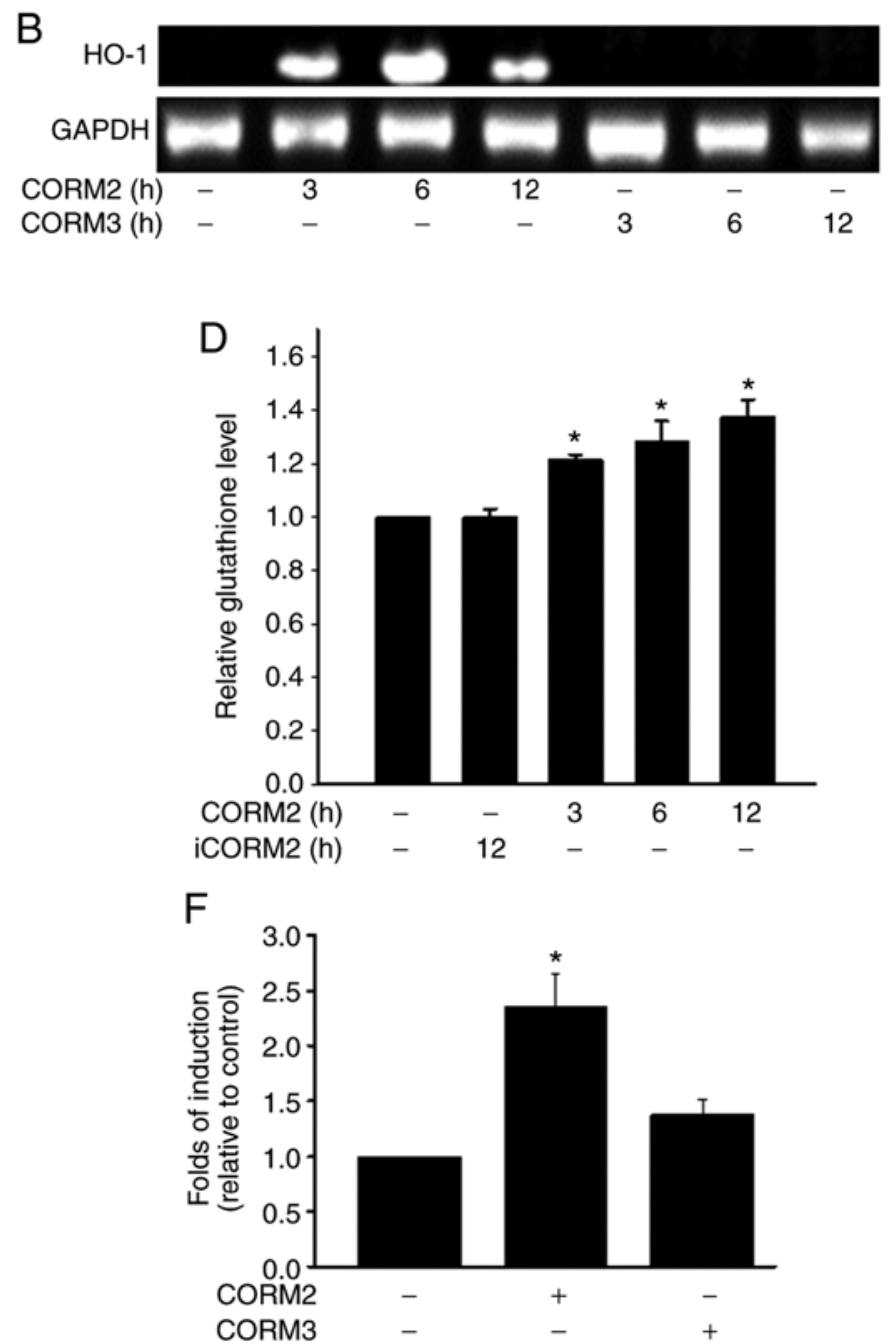

Figure 3. The antioxidant activity of CORM2 was mediated through an increase of the GSH level. (A) RPE cells were pretreated with $25 \mu \mathrm{M}$ CORM2 or CORM3 for $12 \mathrm{~h}$, then treated with $1 \mathrm{mM}$ of $\mathrm{H}_{2} \mathrm{O}_{2}$ for $1 \mathrm{~h}$, and cell viability was measured. The results shown are the mean \pm standard error. * $\mathrm{P}<0.05$ compared with untreated cells, ${ }^{\text {"P}}<0.05$ compared with $\mathrm{H}_{2} \mathrm{O}_{2}$ alone (mean \pm standard error). (B) RPE cells were treated with $25 \mu \mathrm{M}$ CORM2 and CORM3 for the indicated time periods and then subjected to RT-PCR analysis. (C) RPE cells were treated with $25 \mu \mathrm{M}$ CORM2 and CORM3 for the indicated time periods and subjected to RT-PCR analysis. (D and E) RPE cells were exposed to $25 \mu \mathrm{M}$ CORM2 or iCORM2 for the indicated time periods and the intracellular GSH and GSSG levels were then measured. The results shown are the mean \pm standard error. ${ }^{*} \mathrm{P}<0.05$ compared with untreated cells. (F) Cells were transfected with an ARE-luciferase construct. After $12 \mathrm{~h}$, the cells were treated with $25 \mu \mathrm{M}$ CORM 2 and CORM3. All values are presented as mean \pm standard error. ${ }^{*} \mathrm{P}<0.05$. RPE, retinal pigment epithelium; CORM, carbon monoxide-releasing molecule; iCORM2, inactive CORM2; GSH, reduced glutathione; GSSG, oxidized GSH; HO-1, heme oxygenase 1; GCL, glutamate-cysteine ligase; GCLC, GCL catalytic subunit; GCLM, GCL modifier subunit; RT-PCR, reverse transcription-PCR.

inhibited by pretreatment with $25 \mathrm{mM}$ CORM2 and CORM3 for 3-6 h (Fig. 5A). ICAM-1 is a major component in leukocyte adhesion (5). Therefore, we next examined the effects of CORM2 and CORM3 on the expression of adhesion molecules in ARPE-19 cells. It was observed that pretreatment of ARPE-19 cells with CORM2 and CORM3 for $12 \mathrm{~h}$ significantly inhibited TNF $\alpha$-induced ICAM-1 expression. Pretreatment of ARPE-19 cells with CORM2 was found to have inhibited TNF $\alpha$-induced ICAM-1 expression after $1 \mathrm{~h}$, but its effect became weaker over time (Fig. 5B). By contrast, the inhibitory effect of CORM3 did not begin until after $3 \mathrm{~h}$ of pretreatment, but its effect lasted for up to $12 \mathrm{~h}$ (Fig. 5C). In addition, the ICAM-1 mRNA levels were analyzed using RT-PCR. Pretreatments with CORM2 and CORM3 were conducted at 3 and $6 \mathrm{~h}$, and it was observed that these treatments decreased the ICAM-1 mRNA levels consistently with the protein levels (Fig. 5D).
Effect of CORMs on TNF $\alpha$-induced I $\kappa B \alpha$ degradation and $N F-\kappa B$ nuclear translocation. A previous study demonstrated that TNFa induces the upregulation of ICAM-1 through an $\mathrm{NF}-\kappa \mathrm{B}$ activation pathway (7). In the present study, it was examined whether CORM2 and CORM3 regulate $\mathrm{TNF} \alpha$-induced $N F-\kappa \mathrm{B}$ activation. Degradation of the inhibitory protein I $\mathrm{B} \mathrm{B} \alpha$ was blocked by CORM 2 and CORM3 treatment (Fig. 6A). From 3 to $6 \mathrm{~h}$ after CORM2 and CORM3 pretreatment, $\mathrm{TNF} \alpha$-induced $\mathrm{NF}-\kappa \mathrm{B} / \mathrm{p} 65$ nuclear translocation was decreased (Fig. 6B). The effect of CORM2 and CORM3 on nuclear translocation were further tested by immunostaining with a p65 antibody to determine $\mathrm{NF}-\kappa \mathrm{B}$ translocation, and an inhibitory effect was found to be associated with the 6-h pretreatment (Fig. 6C). In addition, we tested whether CORM2 and CORM3 inhibit TNF $\alpha$-induced p65 activation at the transcriptional level by using an $\mathrm{NF}-\kappa \mathrm{B}$ reporter assay. After 
A
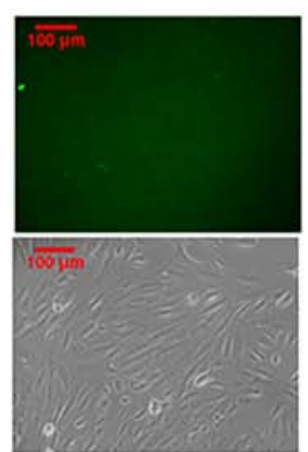

Blue light (h)
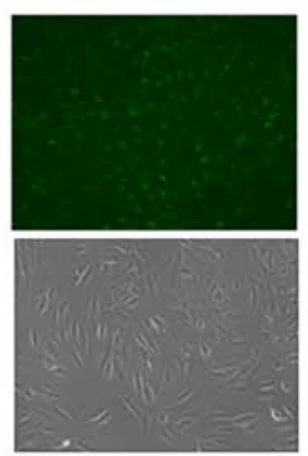

6

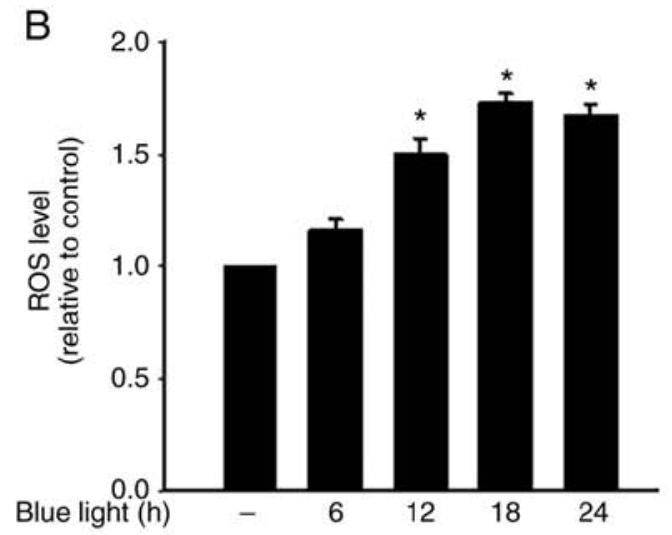

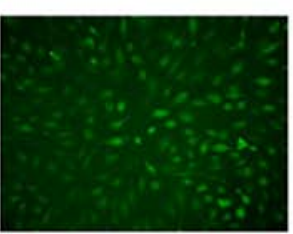

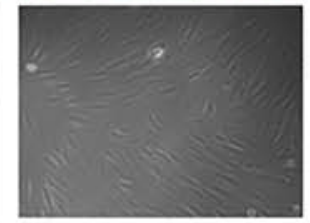

12
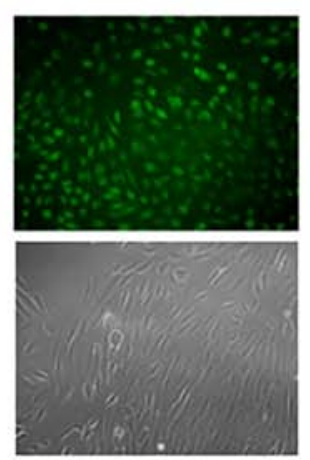

18
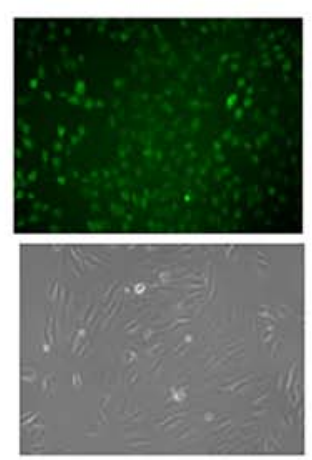

24

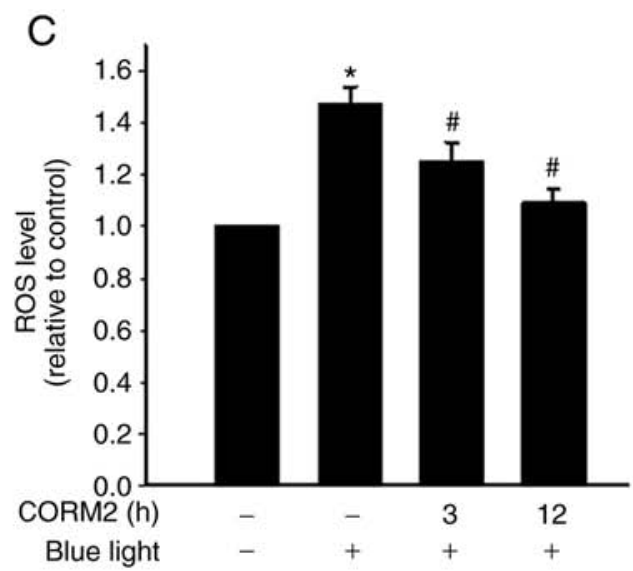

Figure 4. Antioxidant activity of CORM2 against blue light-induced oxidative stress. (A and B) RPE cells were stimulated with blue light for the indicated times and ROS production was measured using the DCFH-DA fluorogenic probe. The intracellular ROS levels were detected by fluorescence microscopy or spectrofluorophotometry. The results shown are the mean \pm standard error. ${ }^{*} \mathrm{P}<0.05$ compared with untreated cells. All values were normalized to the cell numbers. Scale bar, $100 \mu \mathrm{m}$. (C) RPE cells were pretreated with $25 \mu \mathrm{M}$ CORM2 for 3 or $12 \mathrm{~h}$ and then exposed to blue light for $24 \mathrm{~h}$ and the ROS levels were detected. The results shown are the mean \pm standard error. ${ }^{*} \mathrm{P}<0.05$ compared with untreated cells, ${ }^{\text {"P }}<0.05$ compared with blue light alone (mean \pm standard error). RPE, retinal pigment epithelium; CORM, carbon monoxide-releasing molecule; ROS, reactive oxygen species.
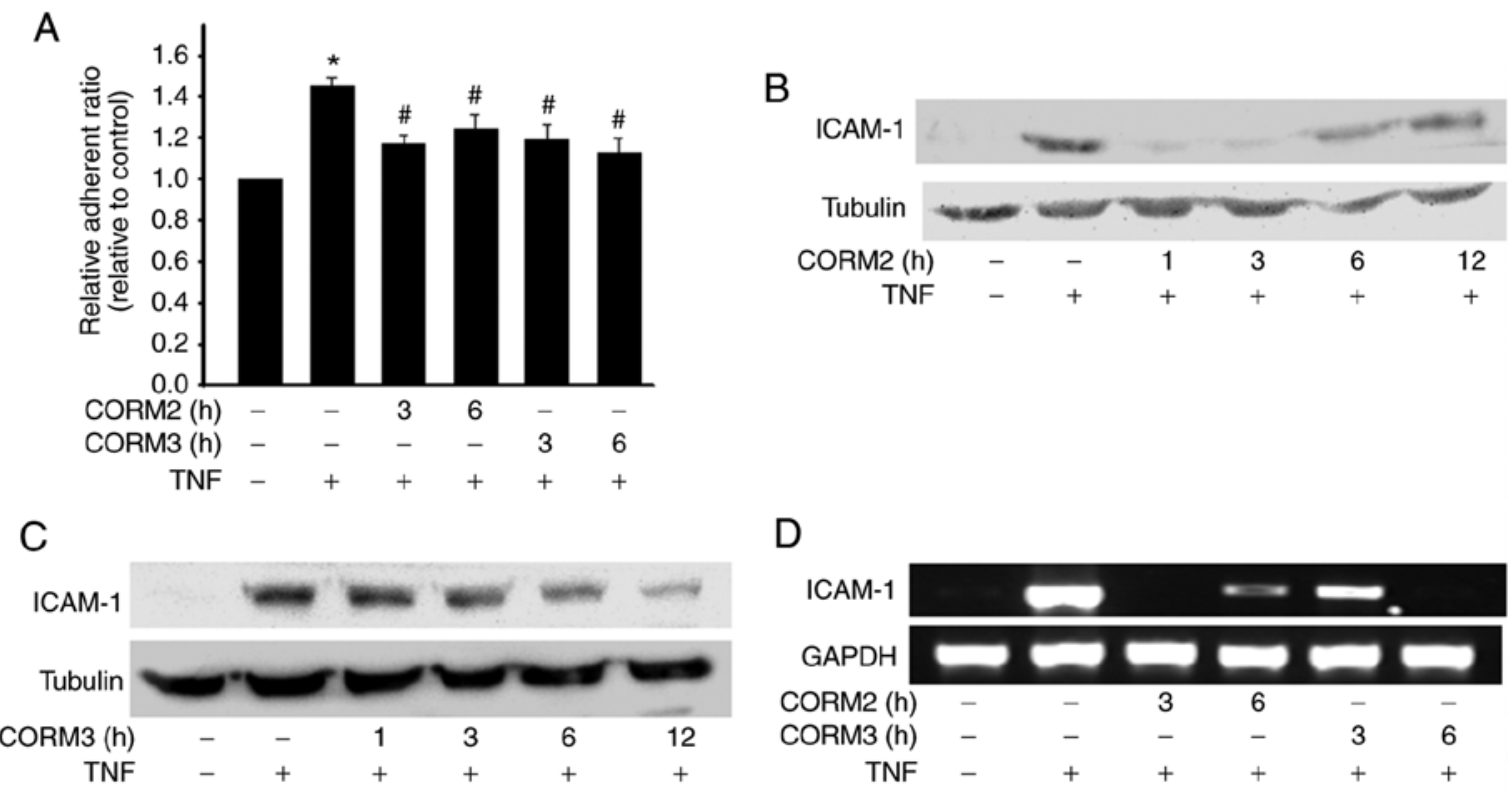

D

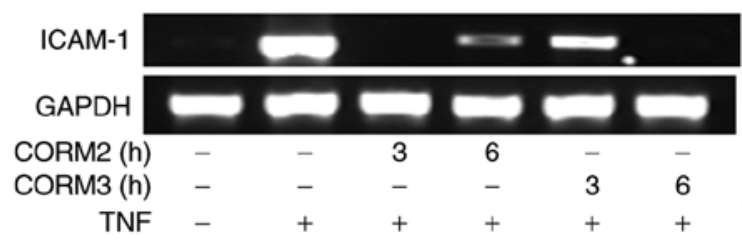

Figure 5. CORM2 and CORM3 inhibit monocyte adhesion and ICAM-1 expression. (A) RPE cells were pretreated with or without $25 \mu \mathrm{M}$ CORM2 and CORM3 for the indicated time periods and then stimulated with $100 \mathrm{U} / \mathrm{ml} \mathrm{TNF} \alpha$ for $4 \mathrm{~h}$. The fluorescence-labeled THP-1 cells were added to the treated cells and incubated for $30 \mathrm{~min}$. The data are presented as relative adherent ratio compared to the untreated control. * $\mathrm{P}<0.05$ compared with the untreated cells, ${ }^{\#} \mathrm{P}<0.05$ compared with TNFa alone. (B and C) RPE cells were pretreated with $25 \mu \mathrm{M}$ CORM 2 and CORM 3 for the indicated time periods, incubated with or without $100 \mathrm{U} / \mathrm{ml}$ TNF $\alpha$ for $4 \mathrm{~h}$ and analyzed by western blotting. (D) RPE cells were pretreated with $25 \mu \mathrm{M}$ CORM 2 and CORM3 for the indicated time periods, incubated with or without $100 \mathrm{U} / \mathrm{ml} \mathrm{TNF} \alpha$ for $4 \mathrm{~h}$ and analyzed by reverse transcription-PCR. RPE, retinal pigment epithelium; CORM, carbon monoxide-releasing molecule; ICAM, intercellular adhesion molecule; TNF, tumor necrosis factor. 
A
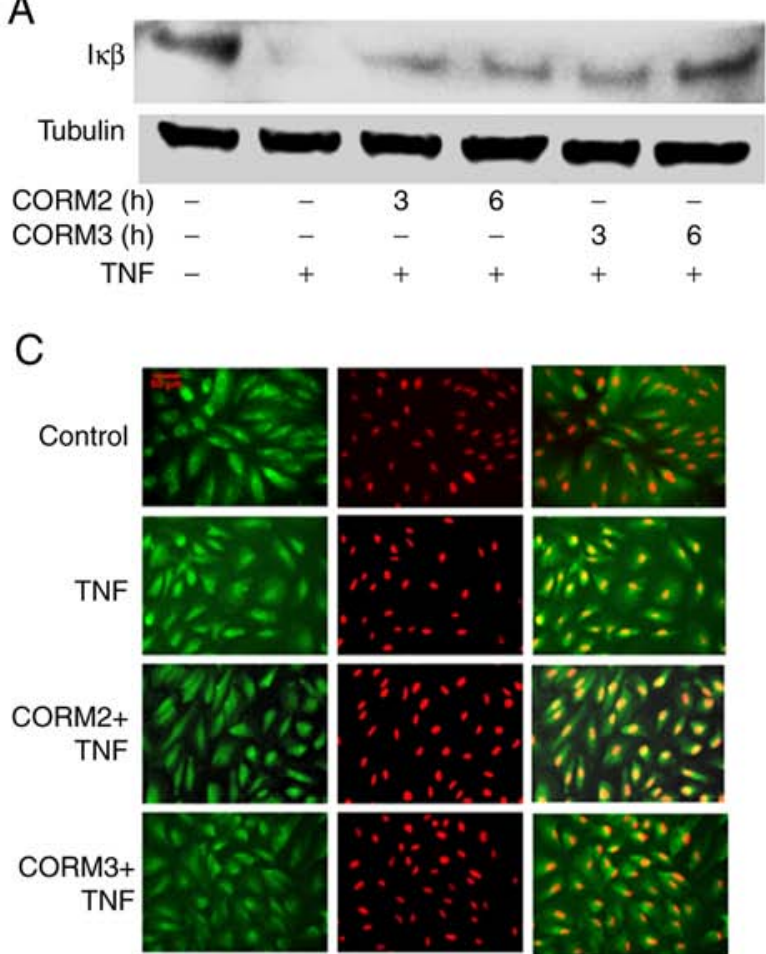

P65

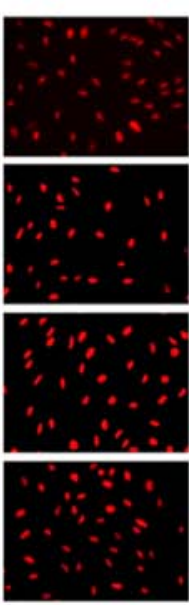

Nuclear

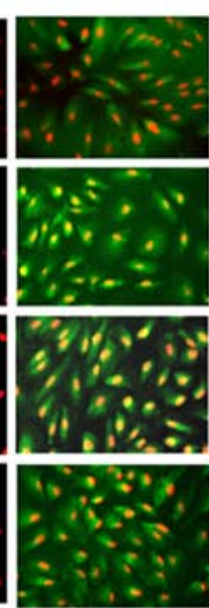

Merged
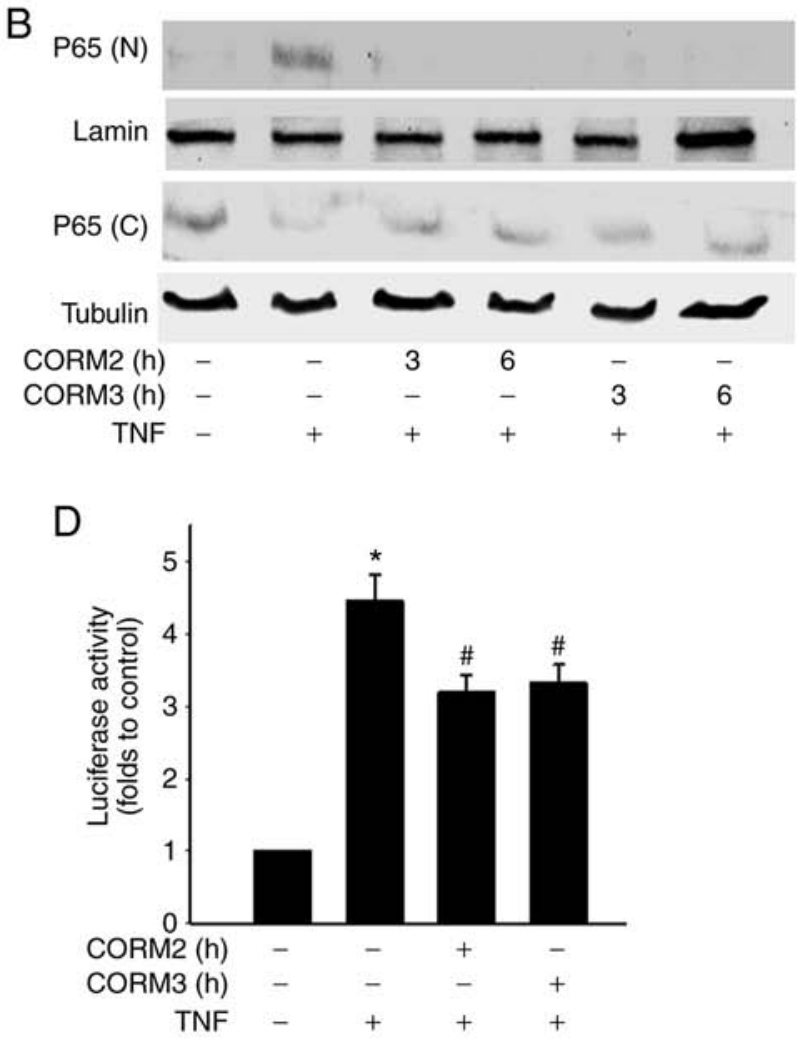

Figure 6. CORMs inhibit TNF $\alpha$-induced I $\kappa \mathrm{B} \alpha$ degradation and NF- $\kappa \mathrm{B}$ nuclear translocation. (A) RPE cells were induced by $100 \mathrm{U} / \mathrm{ml} \mathrm{TNF} \alpha$ for 30 min, and a proportion of these cells was then pretreated with $25 \mu \mathrm{M}$ CORM2 and CORM3 for the indicated time periods. Cell lysates were prepared and then subjected to western blotting. (B) RPE cells were preincubated with $25 \mu \mathrm{M}$ CORM2 and CORM3 for the indicated time periods and then stimulated with TNF $\alpha$. Cytosolic (C) and nuclear (N) extracts were prepared and subjected to western blotting. (C) RPE cells were pretreated with CORM2 and CORM3 for 6 h and

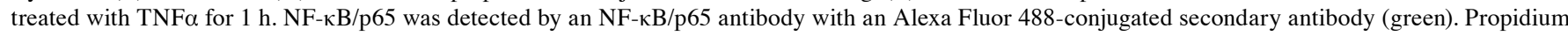
iodide was used to stain for DNA (red). The merged image displays yellow colored nuclei during NF- $\kappa \mathrm{B}$ nuclear translocation. Scale bar, $50 \mu \mathrm{m}$. (D) RPE cells were cotransfected with the construct of NF- $\mathrm{NB}$ luciferase and $\beta$-galactosidase for $16 \mathrm{~h}$. Cells were then treated to $25 \mu \mathrm{M}$ CORM 2 and CORM 3 for $6 \mathrm{~h}$ and stimulated with TNF $\alpha$ for another $4 \mathrm{~h}$. Luciferase activity was normalized against $\beta$-galactosidase activity. ${ }^{*} \mathrm{P}<0.05$ compared with the untreated cells, ${ }^{\#} \mathrm{P}<0.05$ compared with TNF $\alpha$ alone. RPE, retinal pigment epithelium; CORM, carbon monoxide-releasing molecule; TNF, tumor necrosis factor; NF- $\kappa \mathrm{B}$, nuclear factor- $\kappa \mathrm{B}$.

pretreatment and a subsequent delay of $12 \mathrm{~h}$, a luciferase assay was employed (Fig. 6D) to confirm whether TNF $\alpha$-induced $\mathrm{NF}-\kappa \mathrm{B}$ activation was inhibited. Collectively, our experiments demonstrated that CORM2 and CORM3 inhibited NF- $\mathrm{BB}$ nuclear translocation and activation.

CORMs prevented the migration of ECs. VEGF-induced angiogenesis plays a pivotal role in the choroidal neovascularization that characterizes the wet form of AMD (2). To determine whether $\mathrm{CO}$ could inhibit EC migration, a scratch assay was used, and it demonstrated that VEGF induced the migratory capacity of ECs. VEGF-induced migration was decreased through treatment with $25 \mathrm{mM}$ CORM 2 and CORM3 (Fig. 7A). The results of Transwell assay revealed that CORMs considerably reduced the number of migrating cells on the membrane filter compared with the VEGF-containing medium (Fig. 7B). Collectively, these results suggest that CORM2 and CORM3 contribute to the inhibition of the migration capacity of ECs.

\section{Discussion}

RPE cells are a component of the outer blood-retinal barrier located between the blood vessels of the choroid and the outer segments of the photoreceptors. They are vital for protecting the retina from excessive light exposure, oxidative stress and immune responses $(24,25)$. In several retinal diseases, including AMD, the dysfunction of RPE cells is a crucial event in the disease process (4). How CORMs can cross the blood-retinal barrier is not fully understood, but released CO gas is considered to cross biological membranes (19). This suggests that CORMs may act as a therapeutic target to initiate protective mechanisms in the retina. The present study investigated the protective effects of CORMs against blue light-induced cell injury, TNF- $\alpha$-induced inflammation and VEGF-induced cell migration.

RPE cells are sensitive to blue light. The present study demonstrated that blue light exposure induced cell injury and caused cell apoptosis (Fig. 1C). Our results also confirmed an increase in ROS levels in blue light-exposed RPE cells (Fig. 4A). A previous study demonstrated that blue light-induced mitochondrial ROS accumulation may lead to cell death (26), and oxidative stress may be responsible for the blue light-induced cell apoptosis. Consistently, we found that CORMs effectively reduced cleaved PARP-1 and maintained mitochondrial membrane potential in blue light-exposed RPE cells (Fig. 2). However, the protective mechanisms of CORM2 and CORM3 


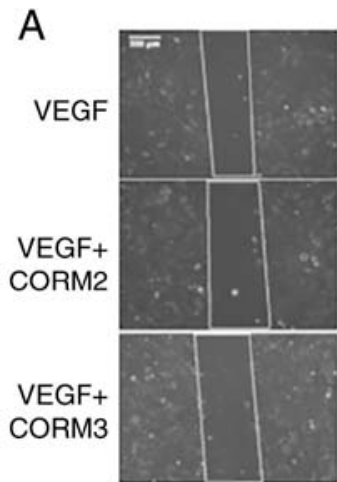

$\mathrm{Oh}$

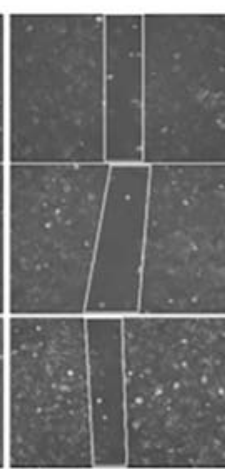

$12 \mathrm{~h}$

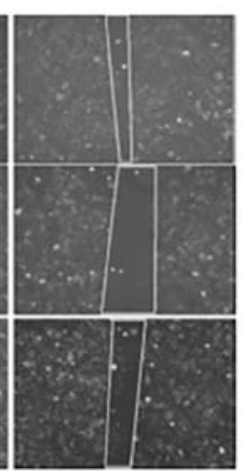

$24 \mathrm{~h}$

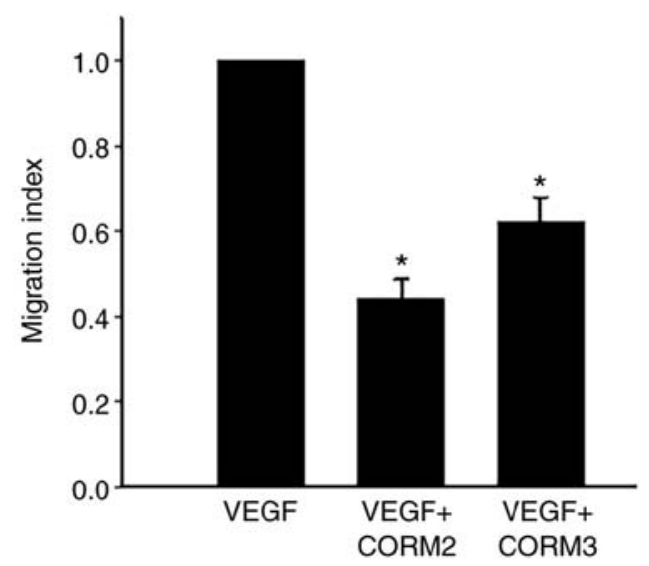

B
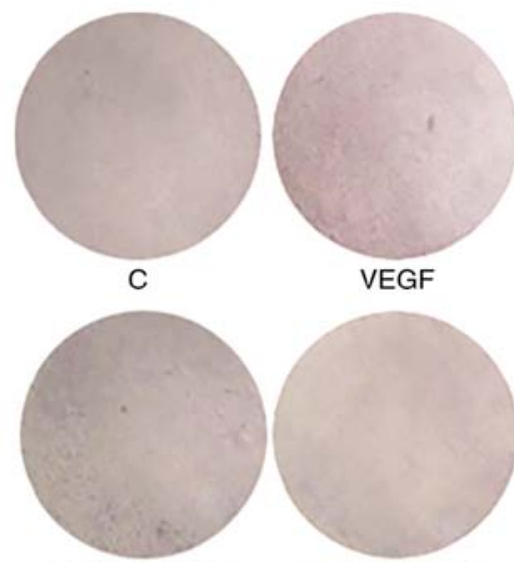

VEGF+CORM2

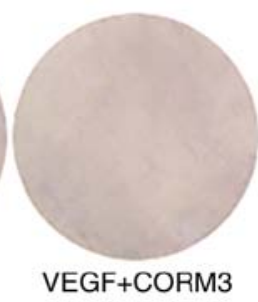

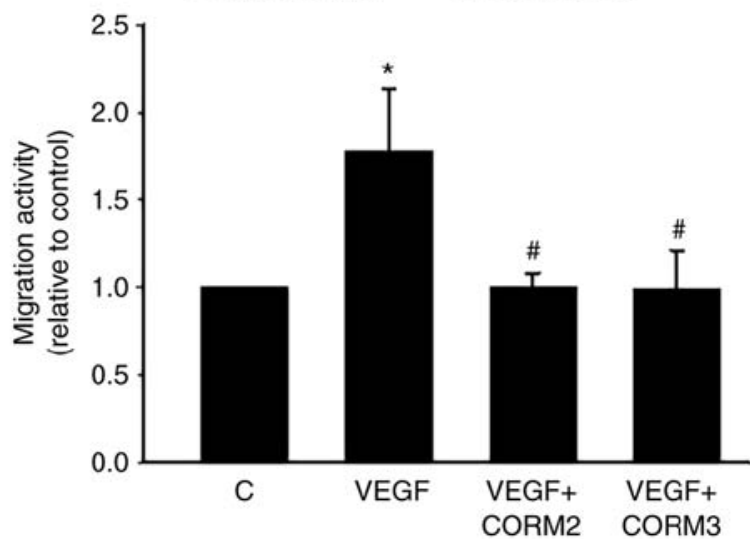

Figure 7. CORMs prevent the migration of ECs. (A) ECs were treated in $10 \mathrm{ng} / \mathrm{ml}$ VEGF and incubated with or without $25 \mu \mathrm{M}$ CORM2 and CORM3 in serum-free medium for the indicated times. The image data were quantified to a migration index, as mentioned in Materials and methods. The data are expressed as means \pm standard error from the results of three independent studies. Scale bar, $200 \mu \mathrm{m}$. (B) In the Transwell assay, ECs were preincubated with or without $25 \mu \mathrm{M}$ CORM2 and CORM3 for $6 \mathrm{~h}$, stimulated with VEGF $(10 \mathrm{ng} / \mathrm{ml})$ for $24 \mathrm{~h}$ and then the migrated stained cells were extracted and determined at $570 \mathrm{~nm}$. The data are expressed as the relative ratio compared to untreated cells. ${ }^{\text {"P }}<0.05$ compared with the untreated cells, ${ }^{\prime \prime} \mathrm{P}<0.05$ compared with VEGF alone. ECs, endothelial cells; CORM, carbon monoxide-releasing molecule; VEGF, vascular endothelial growth factor.

were compared with respect their effects of blue light-induced cytotoxicity. It was observed that CORM2 exerted a stronger protective effect compared with that of CORM3 in preventing blue light-induced cytotoxicity (Fig. 1D). A possible explanation is that the lipid-soluble CORM2 was more efficient than the water-soluble CORM3 in its antioxidant role (Fig. 3A).

Inflammation is a defense mechanism that is triggered by tissue damage due to various causes. Chronic inflammation is a prolonged condition in which damaged tissues attempt to self-repair, leading to tissue remodeling and possible dysfunction. Chronic inflammation is the common pathological basis for certain age-associated diseases, such as AMD. Local inflammation and immune-mediated processes play a key role in AMD pathogenesis $(4,5)$. The results of the present study demonstrated that treatment with CORMs conferred anti-inflammatory protection on cytokine-treated RPE cells, and that CORM2 and CORM3 enhanced the inhibition of TNF- $\alpha$-induced monocyte-RPE interaction by downregulating the expression of ICAM-1. It was demonstrated that CORM2 and CORM3 exerted an anti-inflammatory effect on RPE cells, and this effect was characterized by inhibition of TNF- $\alpha$-induced expression of ICAM-1 with respect to the molecular mechanisms of $N F-\kappa B$ translocation and I $\mathrm{Ba}$ degradation. A particularly notable finding was that the lipid-soluble CORM2 and water-soluble CORM3 displayed different patterns in their anti-inflammatory effects by blocking ICAM-1 expression (Fig. 5) and degradation of the inhibitory protein $\mathrm{I} \kappa \mathrm{B} \alpha$ (Fig. 6A). A shown in Fig. 5B and $\mathrm{C}$, CORM2 pretreatment exert its inhibitory effect on ICAM-1 expression in 1 and $3 \mathrm{~h}$, while the inhibitory effect of CORM3 is observed after $6 \mathrm{~h}$ of pretreatment. A possible explanation is the lipid solubility of CORM2, which enables it to exert its anti-inflammatory effects more quickly compared with the water-soluble CORM3. The lipid-soluble CORM2 may pass through cell membranes and more efficiently release $\mathrm{CO}$ at the targets, whereas CORM3 may release $\mathrm{CO}$ at a certain concentration outside the cells.

The effects of CORM2 are mediated through HO-1 induction in various systems $(14,15,27)$. In the present analyses, a significant increase in HO-1 protein level was observed following treatment with CORM2, but not CORM3, for $3 \mathrm{~h}$ (Fig. 3B). This finding suggests the involvement of HO-1 in the CORM2-mediated antioxidant effect during long-term treatment. Although the half-life of CORM2 is short ( 20 min), CORM2 triggers a positive feedback loop through increasing the HO-1 expression to maintain the antioxidant effect of $\mathrm{CO}$ for $12 \mathrm{~h}$ (Fig. 3A).

GSH plays numerous roles in protecting cells from oxidants and maintaining cellular thiol redox state. An imbalance in the cellular thiol redox state has been implicated in the progression 
of AMD (28). Our earlier study reported that lycopene, a natural carotenoid, can increase GSH, which further protects the RPE cells from oxidative stress-induced damage (29). Another study demonstrated that curcumin protects retinal cells from light-induced and oxidative stress-induced damage through Nrf2-dependent upregulation of antioxidative enzymes (30). Our previous studies demonstrated that the GSH-dependent redox state is a major modulator of the anti-inflammatory effects of cinnamaldehyde and $\mathrm{CO}$ in ECs $(31,32)$. CO has been reported to generate mild oxidative stress by inhibition of the function of cytochrome c oxidase in the mitochondria; however, this mild stress may induce the Nrf2 pathway and, thus, increase GSH levels (32). The present study determined that CORM2 increased the gene expression of both GCLC and GCLM, which are the key rate-limiting enzyme in GSH synthesis (Fig. 3C). Additional experiments demonstrated that CORM2 increased the intracellular GSH level and Nrf-2 activity in RPE cells (Fig. 3D and E). There is a possibility that the lipid-soluble CORM2 can more efficiently reach an intracellular concentration to increase antioxidant activity. In the present study, it was demonstrated that CORM2 could abolish blue light-induced oxidative stress (Fig. 4C). Thus, the increased GSH level is a key contributor to the cytoprotective effect of CORM2.

AMD is a major cause of vision loss among elderly people. The neovascular form (wet AMD) is characterized by the growth of blood vessels from the choroid toward the retina (1). VEGF plays a critical role in the pathophysiological process of neovascular AMD (33). Anti-VEGF therapy is currently the standard of care for wet AMD (34). A previous study demonstrated that $\mathrm{CO}$ inhibits sprouting angiogenesis and VEGF receptor-2 phosphorylation (35). In addition, our previous study demonstrated that CORM2 induced nitric oxide (NO) production in ECs (36). NO acts as a potent vasodilator and plays a key role in the physiological regulation of ocular blood flow. The present study demonstrated that treatment with $25 \mathrm{mM}$ CORM2 and CORM3 enhanced the suppression of VEGF-induced migration (Fig. 7A). In Transwell invasion assays, CORMs reduced cell migration toward the VEGF-containing medium (Fig. 7B). Collectively, these results suggest that CORM2 and CORM3 contribute to the inhibition of the migration and invasion capacity of ECs.

In conclusion, the present research demonstrated that CORM2 and CORM3 exhibited different patterns of anti-inflammatory effects and played pivotal roles in the anti-inflammatory process through the suppression of $\mathrm{NF}-\kappa \mathrm{B}$ activation in ARPE-19 cells. Compared with CORM3, CORM2 was more efficient in increasing antioxidant enzyme expression, resulting in more prominent cytoprotective effects. A better understanding of the functional mechanisms of CORMs may contribute to the development of an effective CO-releasing model for therapeutic application in pathological eye conditions.

\section{Acknowledgements}

The authors would like to thank Kai-Qin Yang, Yu-Zhang Chen, Jing-Yao Huang and Zi-Qiao Lan for their assistance with selected experiments.

\section{Funding}

The present study was supported by grants from the National Science Council of Taiwan (no. 105-2320-B-415-007) and the Chiayi Christian Hospital (grant no. R107-20).

\section{Availability of data and materials}

The datasets used and/or analyzed during the present study are available from the corresponding author on reasonable request.

\section{Authors' contributions}

PMY, KCC and BSW conceived and designed the experiments. PMY, KCC and SHY performed all experiments. PMY and BSW analyzed the data. BSW wrote and revised the manuscript. All authors have read and approved the final manuscript.

\section{Ethics approval and consent to participate}

Not applicable.

\section{Patient consent for publication}

Not applicable.

\section{Competing interests}

All the authors declare that they have no competing interests.

\section{References}

1. Kokotas H, Grigoriadou M and Petersen MB: Age-related macular degeneration: Genetic and clinical findings. Clin Chem Lab Med 49: 601-616, 2011.

2. Kent D and Sheridan C: Choroidal neovascularization: A wound healing perspective. Mol Vis 9: 747-755, 2003.

3. Vicente-Tejedor J, Marchena M, Ramírez L, García-Ayuso D, Gómez-Vicente V, Sánchez-Ramos C, de la Villa P and Germain F: Removal of the blue component of light significantly decreases retinal damage after high intensity exposure. PLoS One 13: e0194218, 2018.

4. Strauss O: The retinal pigment epithelium in visual function. Physiol Rev 85: 845-81, 2005.

5. Cousins SW, Espinosa-Heidmann DG and Csaky KG: Monocyte activation in patients with age-related macular degeneration: A biomarker of risk for choroidal neovascularization? Arch Ophthalmol 122: 1013-1018, 2004.

6. Yang L, Froio RM, Sciuto TE, Dvorak AM, Alon R and Luscinskas FW: ICAM-1 regulates neutrophil adhesion and transcellular migration of TNF-alpha-activated vascular endothelium under flow. Blood 106: 584-592, 2005.

7. Ledebur HC and Parks TP: Transcriptional regulation of the intercellular adhesion molecule-1 gene by inflammatory cytokines in human endothelial cells. Essential roles of a variant NF-kappaB site and p65 homodimers. J Biol Chem 270: 933-943, 1995.

8. Tak PP and Firestein GS: NF-kappaB: A key role in inflammatory diseases. J Clin Invest 107: 7-11, 2001.

9. Nakanishi-Ueda T, Majima HJ, Watanabe K, Ueda T, Indo HP, Suenaga S, Hisamitsu T, Ozawa T, Yasuhara H and Koide R: Blue LED light exposure develops intracellular reactive oxygen species, lipid peroxidation, and subsequent cellular injuries in cultured bovine retinal pigment epithelial cells. Free Radic Res 47: 774-780, 2013.

10. Itoh K, Chiba T, Takahashi S, Ishii T, Igarashi K, Katoh Y, Oyake T, Hayashi N, Satoh K, Hatayama I, et al: An Nrf2/small Maf heterodimer mediates the induction of phase II detoxifying enzyme genes through antioxidant response elements. Biochem Biophys Res Commun 236: 313-322, 1997. 
11. Alam J, Stewart D, Touchard C, Boinapally S, Choi AM and Cook JL: Nrf2, a Cap'n'Collar transcription factor, regulates induction of the heme oxygenase-1 gene. J Biol Chem 274 26071-26078, 1999.

12. McMahon M, Itoh K, Yamamoto M, Chanas SA, Henderson CJ, McLellan LI, Wolf CR, Cavin C and Hayes JD: The Cap'n'Collar basic leucine zipper transcription factor Nrf2 (NF-E2 p45-related factor 2) controls both constitutive and inducible expression of intestinal detoxification and glutathione biosynthetic enzymes. Cancer Res 61: 3299-3307, 2001.

13. Townsend DM, Tew KD and Tapiero H: The importance of glutathione in human disease. Biomed Pharmacother 57: 145-155, 2003.

14. Kim KM, Pae HO, Zheng M, Park R, Kim YM and Chung HT: Carbon monoxide induces heme oxygenase-1 via activation of protein kinase R-like endoplasmic reticulum kinase and inhibits endothelial cell apoptosis triggered by endoplasmic reticulum stress. Circ Res 101: 919-927, 2007.

15. Schwer CI, Mutschler M, Stoll P, Goebel U, Humar M, Hoetzel A and Schmidt R: Carbon monoxide releasing molecule-2 inhibits pancreatic stellate cell proliferation by activating p38 mitogen-activated protein kinase/heme oxygenase-1 signaling. Mol Pharmacol 77: 660-669, 2010.

16. Shin DY, Chung J, Joe Y, Pae HO, Chang KC, Cho GJ, Wolf CR, Cavin $\mathrm{C}$ and Hayes JD: Pretreatment with CO-releasing molecules suppresses hepcidin expression during inflammation and endoplasmic reticulum stress through inhibition of the STAT3 and CREBH pathways. Blood 119: 2523-2532, 2012.

17. Ryter SW, Alam J and Choi AM: Heme oxygenase-1/carbon monoxide: From basic science to therapeutic applications. Physiol Rev 86: 583-650, 2006.

18. Bannenberg GL and Vieira HL: Therapeutic applications of the gaseous mediators carbon monoxide and hydrogen sulfide. Expert Opin Ther Pat 19: 663-682, 2009.

19. Queiroga CS, Vercelli A and Vieira HL: Carbon monoxide and the CNS: Challenges and achievements. Br J Pharmacol 172: $1533-1545,2015$.

20. Lian KC, Chuang JJ, Hsieh CW, Wung BS, Huang GD, Jian TY and Sun YW: Dual mechanisms of NF-kappaB inhibition in carnosol-treated endothelial cells. Toxicol Appl Pharmacol 245: 21-35, 2010.

21. Kamencic H, Lyon A, Paterson $\mathrm{P}$ and Juurlink BH: Monochlorobimane fluorometric method to measure tissue glutathione. Anal Biochem 286: 35-37, 2000.

22. Braut-Boucher F, Pichon J, Rat P, Adolphe M, Aubery M and Font J: A non-isotopic, highly sensitive, fluorimetric, cell-cell adhesion microplate assay using calcein AM-labeled lymphocytes. J Immunol Methods 178: 41-51, 1995.

23. Yang D, Elner SG, Bian ZM, Till GO, Petty HR and Elner VM Pro-inflammatory cytokines increase reactive oxygen species through mitochondria and NADPH oxidase in cultured RPE cells. Exp Eye Res 85: 462-472, 2007.

24. Sparrow JR, Hicks D and Hamel CP: The retinal pigment epithelium in health and disease. Curr Mol Med 10: 802-823, 2010.

25. Pavan B and Dalpiaz A: Retinal pigment epithelial cells as a therapeutic tool and target against retinopathies. Drug Discov Today 23: 1672-1679, 2018.
26. King A, Gottlieb E, Brooks DG, Murphy MP and Dunaief JL: Mitochondria-derived reactive oxygen species mediate blue light-induced death of retinal pigment epithelial cells. Photochem Photobiol 79: 470-475, 2004.

27. Choi YK, Kim CK, Lee H, Jeoung D, Ha KS, Kwon YG, Kim KW and Kim YM: Carbon monoxide promotes VEGF expression by increasing HIF-1alpha protein level via two distinct mechanisms, translational activation and stabilization of HIF-1alpha protein. J Biol Chem 285: 32116-32125, 2010

28. Samiec PS, Drews-Botsch C, Flagg EW, Kurtz JC, Sternberg P Jr, Reed RL and Jones DP: Glutathione in human plasma: Decline in association with aging, age-related macular degeneration, and diabetes. Free Radic Biol Med 24: 699-704, 1998.

29. Yang PM, Wu ZZ, Zhang YQ and Wung BS: Lycopene inhibits ICAM-1 expression and NF- $\kappa \mathrm{B}$ activation by Nrf2-regulated cell redox state in human retinal pigment epithelial cells. Life Sci 155: 94-101, 2016.

30. Mandal MN, Patlolla JM, Zheng L, Agbaga MP, Tran JT, Wicker L, Kasus-Jacobi A, Elliott MH, Rao CV and Anderson RE: Curcumin protects retinal cells from light-and oxidant stress-induced cell death. Free Radic Biol Med 46: 672-679, 2009.

31. Liao BC, Hsieh CW, Liu YC, Tzeng TT, Sun YW and Wung BS: Cinnamaldehyde inhibits the tumor necrosis factor-alpha-induced expression of cell adhesion molecules in endothelial cells by suppressing NF-kappaB activation. Effects upon IkappaB and Nrf2. Toxicol Appl Pharmacol 229: 161-171, 2008.

32. Yeh PY, Li CY, Hsieh CW, Yang YC, Yang PM and Wung BS: CO-releasing molecules and increased heme oxygenase-1 induce protein S-glutathionylation to modulate NF-kappaB activity in endothelial cells. Free Radic Biol Med 70: 1-13, 2014.

33. Hernández-Zimbrón LF, Zamora-Alvarado R, Ochoa-De la Paz L, Velez-Montoya R,ZentenoE, Gulias-CañizoR, Quiroz-MercadoH and Gonzalez-Salinas R: Age-related macular degeneration: New paradigms for treatment and management of AMD. Oxid Med Cell Longev 2018: 8374647, 2018.

34. Martin DF, Maguire MG, Ying GS, Grunwald JE, Fine SL and Jaffe GJ: Ranibizumab and bevacizumab for neovascular age-related macular degeneration. N Engl J Med 364: 1897-1908, 2011.

35. Ahmad S, Hewett PW, Fujisawa T, Sissaoui S, Cai M, Gueron G, Al-Ani B, Cudmore M, Ahmed SF, Wong MK, et al: Carbon monoxide inhibits sprouting angiogenesis and vascular endothelial growth factor receptor-2 phosphorylation. Thromb Haemost 113: 329-337, 2015.

36. Yang PM, Huang YT, Zhang YQ, Hsieh CW and Wung BS: Carbon monoxide releasing molecule induces endothelial nitric oxide synthase activation through a calcium and phosphatidylinositol 3-kinase/Akt mechanism. Vascul Pharmacol 87: 209-218, 2016. 